\title{
Social Responsibility: A New Challenge in Graduate University Education
}

\author{
ROBERTO G. LENCINA \\ Facultad de Ciencias Naturales e IML-Universidad Nacional de Tucumán, Argentina \\ robertolencina@yahoo.com.ar
}

\begin{abstract}
The key for including ethics and social responsibility (SR) in the university curricula is the recognition that, in our world, academia has become a relevant place for the production of knowledge and the promotion of values that support the integration of economic, social and environmental aspects, in order to build a better society. universities have become institutions with technical-professional and ethical-social objec-tives, whose purpose is to add value to society and all its stakeholders. At the heart of this assertion there is the conviction that the RS of the university acts as a double bridge: firstly, as a link between ethics and wisdom, then, as a connection between wisdom and commitment to sustainability and social cohesion. The concept of $S R$, in its broadest sense, is perceived in university classrooms as an understandable abstraction imposed by reality itself. Even though it is not yet a formal subject of academic discussions, the truth is that daily professional practice, and the important social questions that practice raises, impose a new agenda in university curriculum design.
\end{abstract}

\section{INTRODUCTION}

S ustainable development does not imply considering the resources of our planet to be intangible, but to promote a harmonic economic development. Any approach to an integral ecology, which by definition includes human beings, needs to take account of the value of labour: "God placed man and woman in the garden he had created (cf. Gen 2:15) not only to preserve it ("keep") but also to make it fruitful ("till")". Labourers and craftsmen thus "maintain the fabric of the world" (Si 38:34). "The Lord created medicines out of the earth, and a sensible man will not despise them" (Si 38:4) (Pope Francis, 2015).

"To take care of the land is not like taking care of a museum, which is a single place to guard, clean and preserve; keeping its pieces of art without any biological life in the best possible state. To take care of the land means to develop it according to its vital possibilities, taking full advantage of those potentials that God has designed, which is, in turn, a scientist's task to keep on discovering, developing to the Common Human Welfare" (Sanchez Sorondo M., 2018).
On the other hand, the first decade of the 2000s was characterized by the emergence and proliferation of conflicts and socio-environmental movements in different communities in Argentina. Among them, those that arose in opposition to large-scale mining projects occupy an important percentage at the national level, with the "Esquel case" being the precedent of the local community option (Wagner, 2010).

\section{CURRENT STATE OF AFFAIRS OF NATURAL RESOURCES}

The permanent and increasing demand for mineral resources has led humanity to discuss the possible social and environmental consequences of the extraction of these products on large scales (Figg. 1 and 2). As a recent fact to prove this, we can see the agreements achieved in Africa (in Congo principally) on deposits of cobalt, copper and molybdenum, metallic minerals, which will constitute the base of the technological advancement. Many are the factors that encourage and push extractive companies to invest on exploration and exploita- 
tion of minerals in different countries of our planet.

The exponential growth of the need for rareearths, lithium, cobalt, graphite, copper, tin, tungsten and other base metals; the technologi- tion plus the legal procedures and social responsibility to carry out the industrial activities.

The key to understanding the institutionalization of ethics and SR in the university is the

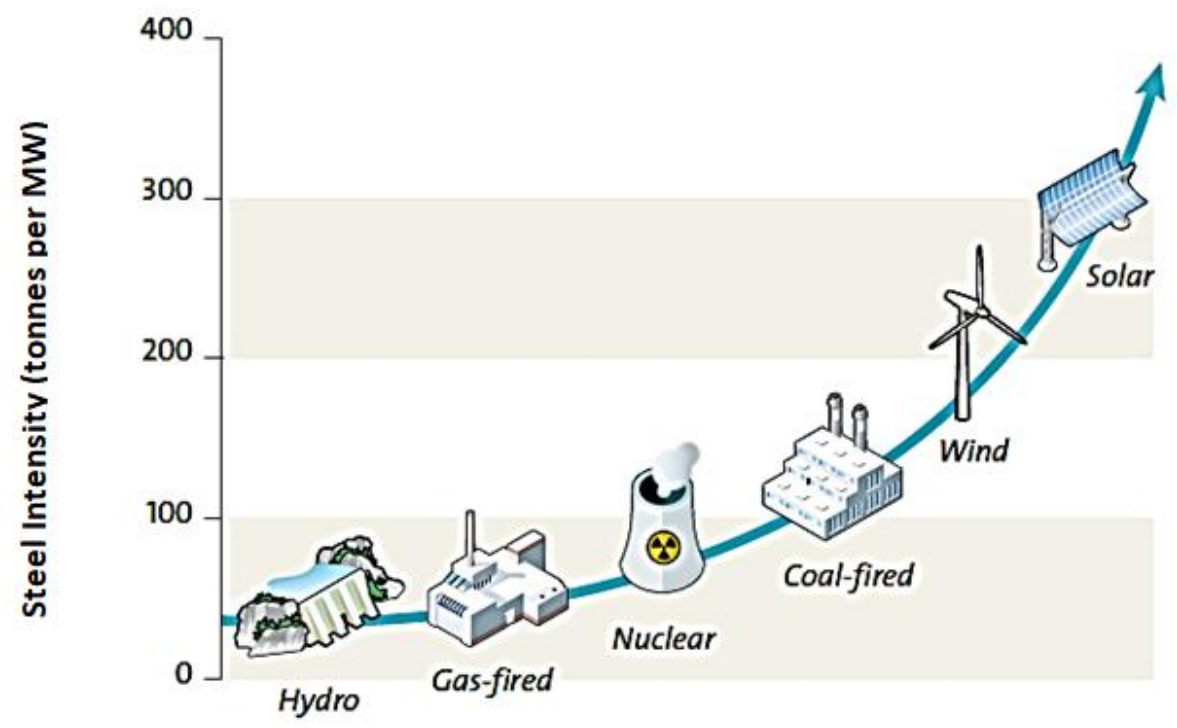

Figure 1: Steel intensity for different power technologies, in tonnes per MW (Wellmer, 2012).

cal change led by electronic mobility; nonconventional energies and the Paris climate agreement, which promises support to countries highly affected by global warming (below 2 degrees Celsius) are only some of the reasons that entice companies to seek profits from natural resources (Meilán, 2018).

\section{THE ROLE OF UNIVERSITIES}

This current situation in natural resources matters demands more and better-prepared professionals, especially geologists and geophysicists who are committed to the specific studies in question. In this vein, Higher Education curricula for these professionals must include the basic meaning and implications of the notion Social Responsibility (SR) and of the new practices related to the extractive industries.

Therefore, university content should be the starting point to begin analyzing, discussing and incorporating all notions related to the traditional practice of exploration and exploita- recognition that, in our world, academia has become a relevant site for the production of knowledge and the promotion of values that support the integration of economic, social and environmental aspects involved in building a better society. In this way, universities have become institutions with technical-professional and ethical-social objectives, whose purpose is to add value to society and all its stakeholders. At the heart of this assertion is the conviction that the SR of the university acts as a double bridge: first, it is a bridge between ethics and wisdom, and second, it is a bridge between wisdom and commitment to sustainability and social cohesion (Guédez, 2012).

SR in its broadest sense appears in university classrooms as an understandable abstraction imposed by reality itself. Even though it is not yet a formal object of academic discussions, at least not in the "hard sciences", the truth is that related daily professional practice, and the strong social questioning that exists are multiplying as a result of extractive industry projects 




Figure 2: The increase in the complexity of metal assemblages in generic products (Reuter and Kojo, 2012).

and impose a new agenda on university culum design.

\section{THE BEGINNING OF THE CRISIS AND THE PROCESS OF DEVELOPING AWARENESS IN SOCIAL RESPONSIBILITY MATTERS}

People's assemblies emerged in Argentina at the beginning of the 21st century as a form of social expression that demanded environmental protection and knowledge about the destination of the income gained from productive projects like:

- Botnia: a conflict about a huge cellulose factory Uruguay built on its side of the Uruguay River (Constanzo, 2009).

- Esquel: the Meridian Gold project that had to be cancelled because of strong popular opposition.

- Famatina: Osisko's gold project in the province of La Rioja that was stopped because of popular opposition.

This marked the beginning of a process that over time gained strength and forced the state and companies to consider this phenomenon. The consequences of these social movements were delays to investments in some cases and the definitive loss of investments in others. In the face of this scenario the Argentine ties could not or did not know how to accompany this process in an organic way; to the contrary, in isolated and spasmodic occurrences universities pronounced themselves in favour of or against natural resource productive initiatives. This information would be of little importance from a purely academic point of view as it would not have an impact on their scientific production or on their research projects, but it is important to the degree it has a large social impact because of bad professional practices in government projects and decisions.

It is generally clear that Argentinian universities did not have the capacity to evaluate the situation correctly, especially with respect to their role in the development of university professionals. The National University of Tucumán is a partner of YMAD (Yacimientos Mineros de Agua de Dionisio), a mixed consortium that has rights to the exploitation of Bajo de la Alumbrera and Farallón Negro mines. In this case, the focus of the discussions since 1997 has been on royalties and on the negative consequences of the mining enterprise. Now Bajo de la Alumbrera is at the final stage and its estimated final closure will be in 2018.

Here the curriculum appears as an absent actor: in spite of the fact that the universities are 
undertaking a large process of accreditation and curricular renovation, SR does not appear among the priorities in academic education in central areas such as geology, engineering, biology, economy and others.

\section{SOCIAL RESPONSIBILITY AS A CROSS- CUTTING CONCEPT IN CURRICULAR DESIGN}

In the face of this reality, university graduate curricular designs should seriously consider the incorporation of content related to SR. There is a need for a broad academic discussion that starts a process of transformation in the perception of the problems. University-private sector-state interaction has to be the engine that drives the changes; there has to be an understanding that curricular designs flow from permanent analysis of the reality that surrounds us and that structures have to be flexible and dynamic. Achieving this will certainly be an enormous challenge in view of the almost total absence of debate on the subject.

Questions about content and strategies have to result from the different perceptions, and from the democratic agreement of the actors involved (teachers, students, graduates, etc.). The truth is that the proposal has to be born from the certainty that this is now a crying need and demand.

The cross-cutting of the proposals, in which each formal and informal curricular space adds to the total, has to be central at the time of final design. This process is necessary to allow graduates to count on at least a minimal vision of real life. In the face of a probable lack of concrete experiences within the universities, we propose internships and paid practice, similar to Canadian summer student programs in state organizations and companies in which SR is part of the experience.

\section{THE LACK OF FORMAL DEBATE ABOUT SR IN ARGENTINE UNIVERSITIES}

In Argentina, especially in Geology, discussion on the issue began in 1988 when the Department of Education and Justice of the Nation (MEJN) summoned representatives of National Universities and Professional Advisory Com- mittees to define the particular professional duties required for a geology degree.

When an agreement was reached to define the Profile of the Geologist, Resolution 210/88 promulgated these requirements (Lacreu, 2005). The formal document defined three elementary aspects that answered to the following questions: What does the geologist know? What can he or she do? What values and basic principles do guide her or him to develop professionally? The last question reflected the challenges that called for discussion of SR issues.

Nevertheless, little was done in the academic curricula of geology after the reforms. In 2008, the notion of SR was a separate point within the Plenary of Agreement N. 44 of the University Advisory Committee. The same meeting set the standards for the process of accreditation following SR standards.

Once the process of accreditation was properly functioning, SR and ethical values contents were incorporated into the geologist's profile.

Even though there has been considerable progress in terms of SR in general, the academic debate was absent until 2017 when it was brought to the fore in the frame of the XX Argentine Geological Congress, held in Tucumán. The event made space for re-opening the debate in some of the scientific meetings and symposia. These showed that there is still much work to do on this issue.

\section{THE AMBIT OF APPLICATION OF SR CURRICULAR CONTENT}

This point of reflection appears almost obvious; however, we want to analyze what are the areas in which to apply the notions and commitments that flow from SR. University, as a place of work permanently linked with society, is without doubt the first place to apply SR in its narrow or broad sense. Convictions clearly have to form the basis of public education policies. That is to say, "I practice what I teach". This is probably the most important point of reference in this process.

To reach this objective there ia a need for an earlier stage that consists of university actors' knowledge of reality; this sensitization could then lead to making decisions on curricular 
matters or at least trigger a discussion that results in a strong desire for change.

Obviously, if SR content is inserted into the universities, a second stage that consists of theoretical-practical preparation of teachers will begin. Workshops and seminars will be good tools with particular modalities that can help with the exchange of opinions and the maturation of the central meanings that each university may want to give to the matter according to its perception of reality and especially the social context in which it carries out its tasks.

Finally, the classroom will be the ambit par excellence within which to work on the proposed concepts. Here, the methodologies will vary with the possibilities of each university. It is important that the crosscutting direction of the contents be clear. Some possible strategies can be internships with precise objectives, consulting for companies and integration with policy decision making.

The final question thus will be "what do we do in the meantime". In this case, the ambit of natural resources productive projects is a good place to introduce contents and principles. The university can work on the transition, proposing consulting assignments to companies in which social perceptions, theoretical frameworks, etc. can be involved.

\section{WORK PROPOSAL WITH TRANSVERSAL SR CONTENT}

At this point, I will share some years of experience both in the university graduate classroom and in concrete work in mining projects (Lencina, 2017). I propose the central axiom:

\section{Knowing $\longrightarrow$ Sensitization $\longrightarrow$ Involve- ment $\longrightarrow$ Commitment $\longrightarrow$ Action}

- Knowing: real case studies will be worked on in the classroom, with a brief orientation guide.

- Sensitization: it will flow from the analysis of the cases from multiple points of view (company employees, community members etc.)
- Involvement: it will be the inexorable next step when I propose trials that include different end points each with its connected arguments.

- Commitment: it is the key in the process. It is the driver that keeps the rest going. At this point I propose concrete actions that can be carried out in the framework of previous agreements that have been signed [internships, coop students, etc.]

- Action: acting is to make things concrete for learning; it is putting tension in convictions and proposals. It means transposition of ideas to the real world. I propose that students develop their own strategies than can be carried out in their projects (visits to community members, life stories, and informal meetings with company employees to exchange views, etc.).

Likewise, it is important to consider that in the natural resource projects the training has to include the professionals in a project, and all others from management levels down to employees with minor responsibilities. An additional object for this training task has to be the policy sector and the (actual) extractive productive projects in progress have to provide the opportunity for this experience. Other points to for consideration include:

- Public presentations, formal project dissemination events, meetings with different political groups.

- Social acceptance of the initiatives has to involve the very professionals and employees of the companies; working based on conviction and not based on convenience will always be more sustainable.

- SR in the curriculum is possible, provided those responsible for its design and implementation have been able to previously pass through the logical process of maturation of ideas, perceptions, theoretical frameworks and reigning reality. Its transversality will then be unquestionable because the reference to real cases will necessarily lead each curricular space to deal with the issue and assign classroom time to it. 
The freedom to think and express oneself, without dogmas or intellectual authoritarianism will be very important as part of the process that we suggest initiating in university classrooms and that certainly has an open and proper final outcome for each professional throughout her or his life.

\section{THE FIAMBALÁ CASE, CATAMARCA, ARGENTINA}

One of the major challenges related to obtaining of the social license for a lithium project took place in the district of Fiambalá, Catamarca, Northwest Argentina.

In 2012, inhabitants of Fiambalá and a neighboring city, Tinogasta, were affected by one of the most relevant events in the mining sector: the announcement of possible uranium exploration projects of. The announcement encouraged a great part of the society and some political groups committed to environmental issues to take action using any means to prevent the projects from reaching State' approval.

At the end of 2016, the international company Liex S.A. arrived in Argentina. The company, where I work as consultant, functions as a Neolithium Corp's subsidiary, has also experienced social opposition. In some parts of the country, such as Cauchari, Jujuy, La Carolina, San Luis, opposition to mining led to violence that, in some cases led to ceasing all project activities. In view of the possibility of such outcomes, Liex S.A. began a complex process of social insertion on the basis of dialogue and transparency of operations. At present, the company is properly functioning in the zone and has been accepted by the community. What is more, the same firm has established high standards of SR and environmental ethics. This fact is not only highly estimated by the local government but also by the community and other companies in the field.

To achieve social insertion and acceptance, Liex S.A. is working with a special attention to the community's interests and priorities. The following points are very important in their day-to-day operations:

- Definition of integral policies that include SR among the priorities.
- Convictions that must be adopted by the CEO of the company and transmitted to the whole staff.

- Permanent education of the social actors (employees-community-politicians-mass media).

- Knowledge of the community.

- Dialogue and negotiation.

- Responsibility for the industrial activities of the company.

- Knowledge of the real interests of all actors involved.

- Transparency in the actions.

- Developing agreement.

- To make State-Community-Company work as a single entity.

Moreover, conditions for an effective Social Insertion Policy are the following:

- Creating work teams with social sensibility and experience.

- Investing in community relations from the first steps of activities.

- Performing activities with logical sense.

- Adopting respectful beahviours and humility.

- Knowing and respecting times and processes of local communities.

- Using an ethical approach in every step of the productive process.

- Respecting those who think differently and learning to coexist.

- Respecting the freedom of press and mass media.

\section{CONCLUSION: A PROPOSAL FOR IMPLEMENTING STRATEGIES TO INCORPORATE THE NOTION OF SR IN ARGENTINE UNIVERSITIES}

My experience in numerous mining projects in Argentina; my analysis and participation in different stages of the process of academic incorporation of SR in the career of geology; and the growth of the number of social conflicts linked to the extractive industries, all lead me to conclude that there is a gap between the contents of the curricula and the actual professional practices that university graduates need. Hence, in an attempt to reduce the gap between knowledge and practice, design of the new curricula must consider two dimensions: 


\section{A. Political Dimension}

The actual situation of most extractive enterprises and the obstacles that they have to face due to lack of knowledge about SR and all its implications in the process of social insertion have to become common knowledge, especially for State Organisms. Knowing this state-of-affairs and taking public action on the matter will provide transparency to the affected society and an authorized course of action to industry, according to the standards of SR.

To achieve such a possible solution, University hierarchies and committees should begin dealing with the issue in their Advisory Assemblies and meetings. Maybe, discussing the most troubled and violent situations and registering in a formal document all sort of drawbacks posed either for the industrial group or the society will be useful.

\section{B. Academic Dimension}

University Committees in charge of curriculum designs and career contents must take a prominent role. The starting point to change the situation must center in the institutions that form future professionals. Then, those in charge of the design of higher education courses should be aware of the negative and positive outcomes of including a comprehensive knowledge of SR or lack thereof within the academic curricula. As a complement of the obligatory subjects, the curricula may include complementary subjects directly related to the issue of SR. A place where students can discuss, analyze, evaluate and understand the issue with the guidance of professionals experienced in related matters. Finally, to check the relevance of adopting the proposals or refusing them thorough research is necessary, including surveys and analytical investigations that can prove the socio-economic impact of extractive activities that are socially and environmentally aware.

The road is long and complicated, but reality is actually even more complicated. Transforming reality starting locally and through small actions without neglecting the construction of more favourable scenarios over time will be the challenge to work on.

\section{REFERENCES}

Constanzo M. (2009). Papeleras: un problema de comunicación. Propuesta de plan integral de RR PP para mejorar las relaciones entre Botnia y Gualeguaychú. Proyecto de Graduación. Trabajo Final de Grado, Universidad de Palermo, Argentina (in Spanish).

Guédez V. (2012). La institucionalización de la ética y de la Responsabilidad Social en la universidad: hacia una nueva cultura organizacional. En: Enfoque y Herramientas de Formación en Responsabilidad Social Empresarial. Isabel Licha, Compiladora. PNUD (in Spanish).

Lencina R. (2017). La responsabilidad social como un nuevo desafío curricular en la formación de grado en las universidades argentinas. Actas XX Congreso Geológico Argentino. 7-11 agosto 2017, Tucumán, Argentina (in Spanish).

Meilán D. (2018). El tan resonado "No a la Mineria" ¿Adónde nos lleva? Artículo Revista Mining Press: http://www.miningpress.com/documento /2585/daiel-meilan-que-afecta-a-la-mineria (in Spanish) (accessed 22 February 2018).

Pope Francis (2015). Encyclical Letter "laudato si"” on care for our common home, Chapter One, http://w2.vatican.va/content/francesco/e $\mathrm{n} /$ encyclicals/documents/papafrancesco_20150524_enciclica-laudato-si.pdf (accessed 30 January 2018).

Reuter M., Guyonnet D. and Bleischwitz R. (2012). Vers une utilisation éco-efficace des matières premières minérales. Géosciences, 15, pp. 56-63 (in French).

Reuter M.A. and Kojo I.V. (2012). Challenges of metals recycling. Materia, 2, p.p. 50-56.

Sanchez Sorondo M. (2017). Relevancia de la Encíclica Laudato $\mathrm{Si}$ en el tema de la educación, http://www.javeriana.edu.co/documents/ 15832/5510469/Ponencia+Monsen\%CC\%83 or+Sa \%CC\%81nchez+Sorondo.pdf/14594b b6-36ca-4a01-b285-797db39ae3e6 (in Spanish) (accessed 22 February 2018).

Wagner L. (2010). Problemas Ambientales y Conflicto Social En Argentina. Movimientos socioambientales en Mendoza. La defensa del agua y el rechazo a la megaminería en los inicios del siglo XXI. Argentina. Tesis 
Doctoral, Universidad Nacional de Quilmes (in Spanish).

Wellmer F.-W. (2012). Sustainable Development and Mineral Resources. Géosciences, 15, pp. 8-15. 